\title{
Physico-chemical properties of Guava fruits from organic and conventional cultivation systems
}

\author{
Kajornpong Srinil ${ }^{1}$, Anutida Sugsamran ${ }^{1}$, Suratchaya Sorntammalee ${ }^{1}$, and Sukanya \\ Wichchukit ${ }^{1 *}$ \\ ${ }^{1}$ Kasetsart University (Kamphaeng Saen campus) Department of Food Engineering, Faculty of \\ Engineering, Kamphaeng Saen, Nakhon Pathom 73140, Thailand.
}

\begin{abstract}
This study aimed to evaluate physico-chemical properties of guava fruits, 'Paen Srithong' and 'Kim Ju', from organic and conventional cultivation Systems. Two nearby orchards were selected for the study. Soil chemical attributes, physical properties of guava fruits: weight, density, sphericity, total soluble solids and mechanical testing and chemical properties: ascorbic acid and pectin contents were analysed. The result showed that the organic orchard contained higher levels of soil organic matter, nitrogen, phosphorus and potassium than the conventional orchard. The organic fruits from both cultivars exhibited less density, higher ascorbic acid and higher flesh firmness than the conventional cultivated fruits. 'Paen Srithong' cultivar from organic cultivation system exhibited additional significant differences in bigger size and higher contents in TSS and pectin than the conventional cultivated fruits. This confirmation supports positive consumer perceptions on organic guava fruits. It is very useful for promoting the quality of organic guava fruit and enhancing sale.
\end{abstract}

\section{Introduction}

Recently, the demand for organic food products has been expanding worldwide because of consumer awareness of health and diet. Consumers are willingly to pay high prices for organic foods due to the perception that they are superior to conventional foods in terms of flavors, nutrition, health benefits, cleanness, safety and environmental-friendly production [1]. Organic agricultural production is also recommended as part of the solution to reach the sustainable development goals [2]. Many studies had compared differences in physicochemical and organoleptic properties between organic and conventional fruits and vegetables. However, the results in some produces were inconsistent. This may due to the differences in production scale, soil type and cultivation management. Therefore, comprehensible guidelines should be recommended for obtaining better comparison studies [1].

* Corresponding author: fengskw@ku.ac.th 
Some distinct comparative studies between organic and conventional cultivation systems of fruits were reported, mostly from apples. Golden delicious apples and Gala apples showed that the organic apples of each variety were sweeter, and less tart. They also had higher levels of antioxidants and had better textural properties. Organic strawberries showed intense color, higher levels of sugar content, vitamins and antioxidants and higher resistance to deterioration during marketing conditions. Organic tomato gained higher consumer preferences for better taste, flavor, texture and more juiciness. Intense color also indicates the level of antioxidants. Brighter in red color of organic fresh fruits indicates high level of lycopene for tomatoes and anthocyanin for strawberries [3]-[6]. The intense and distinctive flavor of several organic fruits may come from high content of antioxidants. This content is somewhat associated with lower crop yields. In a conventional cultivation system, synthetic fertilizers are used, more available nitrogen, that leads to high yield gaining. However, some evidences reveal that high yields in some crops can dilute the concentrations of vitamins and antioxidants in plants, consequently, can reduce nutritional quality and flavor in the fruits [3]. Amarante et al. [6] observed that the yield and tree size of organic apples were smaller than the conventional ones. They also found that their organic apple fruits had lower weight but higher density and higher flesh firmness than the conventional ones. The dense structure may come from their smaller cells and less intercellular spaces. Peck et al. [4] observed that organic apples exhibited higher flesh firmness at harvest and during storage time than the apples cultivated from conventional system and integrated system. High antioxidants and low nitrates in organic fruits tends to preserve the fruits; organic fruits tends to store better and have longer shelf life [3]. For sensory evaluations, untrained panelists may report no differences in taste, flavor and texture between organic and conventional production fruits. This reveals that regular consumers might not be able to detect subtle differences between the fruits [4], [6].

Guava (Psidium guajava L.) is a common fruit cultivated in many tropical and subtropical regions of the world. It is well known for its nutritional values, rich source of antioxidants, vitamin C, dietary fiber and minerals such as calcium, phosphorus and iron. Its high concentration of pectin somehow enhances cholesterol reduction and that reduces the risk of cardiovascular diseases [7]. Thailand is one of the leading producers of guava to the global market. The typically recognized varieties in Thailand are 'Klom Salee', 'Paen Srithong' and 'Kim Ju' [8]. 'Paen Srithong' and 'Kim Ju' have been cultivated in both organic and conventional systems. And, the organic ones are sold at a higher price than the conventional ones due to less yield and higher attention. However, like other organic produces, organic guavas are limited sold in a niche market. Many Thai consumers do not clearly understand about organic agricultural management. A lot of them are confused the organic agriculture with safe agriculture and integrated agriculture. The main benefit for health that most Thai people understand and believe is that the organic production can reduce the risk of chemical residues. But, having better quality than conventional fruits is quite skeptical. Therefore, this study aimed to evaluate physico-chemical properties of guava fruits, 'Paen Srithong' and 'Kim Ju', from organic and conventional cultivation Systems. The study focused mainly on a comparison between the cultivation systems on the qualities of these two cultivars. Hoping that the result may provide more information on organic guava fruits and gain more consumers and consequently would enhance more sustainable agricultural practices in Thailand. 


\section{Materials and methods}

\subsection{Fruits and cultivation areas}

Fifty guava fruits of uniform size from two cultivars, 'Kim Ju' and 'Paen Srithong', were purchased directly from orchards under an organic and a conventional cultivation system. The fruits were freshly harvested at a commercial mature-green stage (approx. 100 days after anthesis). They were placed on a granite table in a room at a constant temperature of $25^{\circ} \mathrm{C}$. All measures were conducted within $48 \mathrm{~h}$.

The orchards were located close to each other in Nong Ngu Lueam subdistrict, Mueang district, Nakorn Pathom Province. Therefore, the variations due to microclimate and soil type could be considered little. The organic orchard fertilized soil with manure, repel insects with bio-extract solutions and eliminated only some weeds using garden tools. The conventional orchard used chemical fertilizers NPK 13-13-21, NPK 25-7-7 and NPK 14-14-21 and chemical pesticides and insecticides. Soil sample from each orchard was analysed by the Land Development Regional Office 1, Pathum Thani Province. The office reported the values of $\mathrm{pH}$, electrical conductivity, organic matter, phosphorus and potassium. Nnitrogen content in the soils were not analyzed due to lack of measurement equipment. Therefore, nitrogen contents were estimated from organic matter in the soils. Generally, $1 \%$ organic matter contains about $5 \%$ nitrogen $[9,10]$.

\subsection{Determination of physical properties}

The physical characteristics of the fruits were conducted using methods described by Mohsenin [11]. The 3 dimensions of each fruit sample were measured with a vernier caliper and were calculated to sphericity using Equation 1. The weight of each fruit sample was measured on an electronic balance (BSA3202S, Sartorius, Thailand) and the density was determined using the water displacement method. The color attributes, $\mathrm{L}^{*}, \mathrm{a}^{*}$ and $\mathrm{b}^{*}$ values, of each sample were obtained using a spectrophotometer (Hunterlab Mini Scan EZ, Color Global Co.,Ltd., USA), illuminant D65 and $2^{\circ}$ standard observer.

The mechanical testing of the fruits was measured using a Lloyd universal testing machine (LR50, Ametek, USA) in two modes, puncture testing and Texture Profile Analysis (TPA) testing. The puncture testing was conducted by pressing a cylindrical, stainless steel, probe ( $10.50 \mathrm{~mm}$ in diameter) to move down onto a whole fruit sample for $20 \mathrm{~mm}$ in depth; measurements from 4 positions along radial orientation of the fruit were done. The bioyield point (maximum force) obtained from the data curve by the machine software were taken for the fruit texture evaluation. For the TPA testing, a cylindrical guava flesh specimen $(15 \mathrm{~mm}$ in diameter, $30 \mathrm{~mm}$ in height) was compressed twice at $30 \%$ of the sample height by a flat cylindrical ,stainless steel, probe ( $30 \mathrm{~mm}$ in diameter), a duration time of 75 seconds. This testing represents two bites of human molars. The first bite (first compression) is to predict texture of the fruit. The second bite (second compression) is to confirm and gain more texture information. The parameters derived from the TPA data curve by the machine software, hardness 1, cohesiveness and chewiness, were used for the fruit evaluation.

Additionally, the guava flesh was ground and filtered with straining cloth. The filtrate was collected to determine $\mathrm{pH}$ value using a $\mathrm{pH}$ meter (PB-10, Sartorius, Thailand) and total soluble solids (TSS) using a digital refractometer (PR-101 $\alpha$, Atago, Japan).

$$
\text { Sphericity }=\frac{(a b c)^{1 / 3}}{a}
$$




\subsection{Determination of Ascorbic acid (vitamin C) and pectin contents}

Ascorbic acid in guava fruits was determined using a tritimetric method, following the same procedure used by Abu-Zahra et al. [5]. Ten grams of ground guava flesh was used for each extraction. The extract solution was prepared from Oxalic acid and Glacial acetic acid and the indicator was prepared from 2,6-dichlorobenzenoindophenol.

Pectin in the fruits was extracted using the acidic extraction method adapted from Lew et al. [12]. Four hundred grams of ground guava flesh was mixed with $400 \mathrm{~L}$ of $95 \%$ ethanol and heated at $80^{\circ} \mathrm{C}$ for 10 mins to stop enzymatic reaction. After filtration, the cake was cleaned with water 3 times, squeezed and tray dried at $60^{\circ} \mathrm{C}$ for $6 \mathrm{~h}$. The dried cake was then ground into powder and stored in a desiccator. Pectin was extracted from the powder by adding $0.05 \mathrm{M}$ of $\mathrm{HCl}$ in a ratio of 12:1 ( $\mathrm{mL}$ of $\mathrm{HCl}$ : $\mathrm{g}$ of powder) and heated the mixture at $98^{\circ} \mathrm{C}$ for an hour. Then, the mixture was filtered, the filtrate was collected. The wet powder was underwent the extraction process for one more time. Then, both filtrates were mixed and underwent pectin precipitation by adding $95 \%$ ethanol and kept at $25^{\circ} \mathrm{C}$ for $12 \mathrm{~h}$. The extracted pectin was washed and oven dried at $60^{\circ} \mathrm{C}$ for $4 \mathrm{~h}$. The yield of pectin was calculated by divided the pectin weight with the input powder weight.

\section{Results and discussion}

\subsection{Soil chemical attributes of guava orchards}

Soil analysis for both organic and conventional guava orchards were shown in Table 1. According to the operating manual for soil analysis [13], the soil $\mathrm{pH}$ in both orchards was slightly acidic but not much far from neutrality. Low values of electrical conductivity indicates low salt content in the soils. Which means guava can grow well without salt interference. Unsurprisingly, the organic orchard had higher levels of soil organic matter, nitrogen, phosphorus and potassium than the conventional orchard. The manure fertilized in the organic orchard not only adds essential nutrients to the soil, but also change the soil's structure. Generally, as manure continues to decompose in the soil, it releases nitrogen, phosphorus, potassium and other nutrients to the soil. These nutrients are instantly supplied to plants. Microbes and bacteria in the soil also absorb these nutrients and produce their byproduct called humus. Humus changes the soil's structure to be porous and has good water holding ability [14]. The conventional orchard used chemical fertilizers, which could be easily used by plants. This reveals that nutrient intake was higher than the organic orchard and there would be some nitrates left in the soil.

Table 1. Soil chemical attributes of guava orchards.

\begin{tabular}{|c|c|c|}
\hline Attributes & Conventional orchard & Organic orchard \\
\hline $\mathrm{pH}$ & 6.1 & 6.1 \\
\hline Electrical conductivity $(\mathrm{dS} / \mathrm{m})$ & 0.0756 & 0.1431 \\
\hline Organic matter $(\%)$ & 1.44 & 2.92 \\
\hline Nitrogen $(\%)$ & 0.072 & 0.146 \\
\hline Phosphorus $(\mathrm{mg} / \mathrm{kg})$ & 198 & 366 \\
\hline Potassium $(\mathrm{mg} / \mathrm{kg})$ & 130 & 185 \\
\hline
\end{tabular}




\subsection{Physico-chemical properties of guava fruits}

The physical properties of guava fruits from both conventional and organic orchards were reported in Table 2. 'Kim Ju' fruit from organic orchard had lower weight, but 'Paen Srithong' fruit from organic orchard had higher weight than the fruits from conventional orchard. Smaller fruit sizes were reported in the case of organic orchards such as organic strawberries grown in California [3] and organic apples grown in Brazil [6]. However, properly timed fruit thinning could result low fruit yield but bigger sizes of organic fruits [4]. The organic guava fruits from both cultivars had lower density than the conventional cultivated fruits. This result is different from the organic apple fruits observed by do Amarante et al. [6]. It could be explained that guava fruit has different internal structure from apple fruit. Its cells are not packed tightly and homogeneous as those of an apple fruit. A guava fruit contains hard and semi-hard seeds at the center. High amount of stone cells at the outer mesocarp and less stone cells at endocarp. And these result in gritty texture [15]. This complex physiology of a guava fruit could play an important role on its density. And, it could be surmised that different cultivation systems somehow affect the physiology of the fruits. Further investigations are required.

Both cultivars from both orchards were quite spherical. Organic 'Paen Srithong' fruit was slightly less spherical than the conventional cultivated fruit. This may due to their less symmetrical shapes that quite common found in organic fruits. Both cultivars from the organic orchard elicited darker color than fruit from the conventional orchard. The difference in fruit pigments may associate with a level of antioxidants in the fruit [3]. Ascorbic acid is a prominent antioxidant in guava fruits. It was found that both cultivars from the organic orchard had higher contents of ascorbic acid than fruit from the conventional orchard. No significant difference was found in $\mathrm{pH}$ values of both cultivars from both orchards. The TSS contents between different orchards were not significant different in the case of 'Kim Ju'. But, significant difference was found in the case of 'Paen Srithong'; higher TSS content was observed from organic 'Paen Srithong'. The interpretation could be that the organic orchard seemed to be slightly sweeter than fruit from the conventional orchard. Organic 'Paen Srithong' fruits also contained higher pectin content than conventional fruits. High TSS and pectin contents of organic 'Paen Srithong' fruits could also contribute to their bigger fruit size but less density compared to the conventional cultivated fruits.

The mechanical testing, the maximum force at bioyield point from the puncture testing was used to indicate flesh firmness of the guava fruits. The result in Table 3 shows that both cultivars from the organic orchard exhibited higher bioyield force than fruit from the conventional orchard. This indicates the higher flesh firmness of the organic fruit over the conventional one. Flesh firmness is an important factor for fruit quality for fruits. Many research works on apples reported that consumers rated organic apples for high flesh firmness and they were firmer and crispier when taking out of storage than the conventional cultivated apples [4], [6]. This would be advantageous in the marketplace that the fruit could stay longer in a shelf.

Three parameters of TPA, hardness, cohesiveness and chewiness, were selected to represent the texture of guava fruits as shown in Table 3. No significant difference was found in cohesiveness for both cultivars from both orchards. But, both cultivars from the organic orchard exhibited higher hardness and chewiness values than fruit from the conventional orchard. These values are related to the flesh firmness. When flesh is firm, it would require higher force to bite. Therefore, more energy is also required for chewing the fruit. 
Table 2. Quality attributes of guava fruits.

\begin{tabular}{|l|c|c|c|c|}
\hline \multirow{2}{*}{ Attributes } & \multicolumn{2}{|c|}{ Kim Ju } & \multicolumn{2}{c|}{ Paen Srithong } \\
\cline { 2 - 5 } & $\begin{array}{c}\text { Conventional } \\
\text { orchard }\end{array}$ & Organic orchard & $\begin{array}{c}\text { Conventional } \\
\text { orchard }\end{array}$ & $\begin{array}{c}\text { Organic } \\
\text { orchard }\end{array}$ \\
\hline Weight $(\mathrm{g})$ & $226.481 \pm 23.828^{\mathrm{b}}$ & $205.338 \pm 30.113^{\mathrm{a}}$ & $\begin{array}{c}355.247 \pm \\
50.460^{\mathrm{a}}\end{array}$ & $\begin{array}{c}394.492 \pm \\
71.145^{\mathrm{b}}\end{array}$ \\
\hline $\begin{array}{l}\text { Density } \\
\left(\mathrm{g} / \mathrm{cm}^{3}\right)\end{array}$ & $0.886 \pm 0.080^{\mathrm{b}}$ & $0.792 \pm 0.031^{\mathrm{a}}$ & $0.800 \pm 0.040^{\mathrm{b}}$ & $0.772 \pm 0.037^{\mathrm{a}}$ \\
\hline Sphericity & $0.937 \pm 0.027^{\mathrm{a}}$ & $0.945 \pm 0.023^{\mathrm{a}}$ & $0.955 \pm 0.019^{\mathrm{b}}$ & $0.935 \pm 0.018^{\mathrm{a}}$ \\
\hline${\text { Color: } \mathrm{L}^{*}}^{\mathrm{a}}$ & $69.929 \pm 1.492^{\mathrm{b}}$ & $65.622 \pm 3.839^{\mathrm{a}}$ & $66.419 \pm 1.798^{\mathrm{b}}$ & $64.717 \pm 3.097^{\mathrm{a}}$ \\
\hline \multicolumn{1}{|c|}{$\mathrm{b}^{*}$} & $-6.844 \pm 1.122^{\mathrm{b}}$ & $-7.393 \pm 1.059^{\mathrm{a}}$ & $-7.754 \pm 1.305^{\mathrm{a}}$ & $-7.043 \pm 1.415^{\mathrm{a}}$ \\
\hline $\mathrm{pH}$ & $36.47 \pm 1.361^{\mathrm{a}}$ & $37.448 \pm 2.187^{\mathrm{b}}$ & $37.144 \pm 1.092^{\mathrm{a}}$ & $38.273 \pm 2.865^{\mathrm{b}}$ \\
\hline TSS & $4.089 \pm 0.119^{\mathrm{a}}$ & $4.140 \pm 0.097^{\mathrm{a}}$ & $4.144 \pm 0.097^{\mathrm{a}}$ & $4.031 \pm 0.104^{\mathrm{a}}$ \\
\hline $\begin{array}{l}\text { Ascorbic acid } \\
(\mathrm{mg} / \mathrm{ml})\end{array}$ & $10.00 \pm 1.05^{\mathrm{a}}$ & $9.41 \pm 1.10^{\mathrm{a}}$ & $7.65 \pm 0.55^{\mathrm{a}}$ & $8.19 \pm 0.78^{\mathrm{b}}$ \\
\hline Pectin $(\%)$ & $0.54 \pm 0.18^{\mathrm{a}}$ & $0.76 \pm 0.14^{\mathrm{b}}$ & $0.28 \pm 0.07^{\mathrm{a}}$ & $0.39 \pm 0.10^{\mathrm{b}}$ \\
\hline
\end{tabular}

${ }^{a, b}$ Significant at $\mathrm{p}=0.05$ (a comparison between the cultivation systems for each cultivar).

Table 3. Texture parameters of guava fruits.

\begin{tabular}{|l|c|c|c|c|}
\hline \multirow{2}{*}{ Parameter } & \multicolumn{2}{|c|}{ Kim Ju } & \multicolumn{2}{c|}{ Paen Srithong } \\
\cline { 2 - 5 } & $\begin{array}{c}\text { Conventional } \\
\text { orchard }\end{array}$ & $\begin{array}{c}\text { Organic } \\
\text { orchard }\end{array}$ & $\begin{array}{c}\text { Conventional } \\
\text { orchard }\end{array}$ & $\begin{array}{c}\text { Organic } \\
\text { orchard }\end{array}$ \\
\hline Maximun force & $85.706 \pm 12.403^{\mathrm{a}}$ & $\begin{array}{c}102.845 \pm \\
11.676^{\mathrm{b}}\end{array}$ & $101.505 \pm 11.048^{\mathrm{a}}$ & $\begin{array}{c}114.508 \pm \\
16.146^{\mathrm{b}}\end{array}$ \\
\hline H) & & $\begin{array}{c}137.919 \pm \\
37.769^{\mathrm{b}}\end{array}$ & $146.287 \pm 25.182^{\mathrm{a}}$ & $\begin{array}{c}161.738 \pm \\
33.442^{\mathrm{b}}\end{array}$ \\
\hline Cohesiveness (-) & $0.141 \pm 0.090^{\mathrm{a}}$ & $0.160 \pm 0.081^{\mathrm{a}}$ & $0.189 \pm 0.073^{\mathrm{a}}$ & $0.208 \pm$ \\
& & & & $0.062^{\mathrm{a}}$ \\
\hline Chewiness (N.m) & $0.094 \pm 0.076^{\mathrm{a}}$ & $0.138 \pm 0.102^{\mathrm{b}}$ & $0.173 \pm 0.093^{\mathrm{a}}$ & $0.227 \pm$ \\
& & & & $0.104^{\mathrm{b}}$ \\
\hline
\end{tabular}

${ }^{\mathrm{a}, \mathrm{b}}$ Significant at $\mathrm{p}=0.05$ (a comparison between the cultivation systems for each cultivar).

\section{Conclusions}

Cultivation systems affect physiology of guava fruit growth. Both organic 'Kim Ju' and 'Paen Srithong' exhibited some better qualities than the conventional cultivated fruits, such as higher ascorbic acid content and higher flesh firmness. Additionally, organic 'Paen Srithong' fruits clearly exhibited bigger size and higher contents in TSS and pectin than the conventional cultivated fruits. These evidences confirm positive consumer perceptions. This information can be used for promoting organic guava fruit. Organic guava fruit will be perceived as worth purchasing since its quality fulfills consumers' health benefits. And, this could significantly contribute to organic agricultural sustainability.

This work was financially supported by the Faculty of Engineering at Kamphaeng Saen, Kasetsart University, Thailand. 


\section{References}

1. G. E. Lester, Hort Sci. 41, 296-300 (2006)

2. Organic agriculture and the sustainable development goals part of the solution. URL: https://www.eosta.com/sites/www.natureandmore.com/files/documenten/nm19_329_r eport_nm_lr.pdf

3. Do organic fruits and vegetables taste better than conventional fruits and vegetables? URL: http://citeseerx.ist.psu.edu/viewdoc/download;jsessionid=1 A9F409182B8AF16A747 A26DFB194CEA?doi=10.1.1.625.9687\&rep=rep1\&type $=$ pdf

4. G. M. Peck, P. K. Andrews, J. P. Reganold, J. K. Fellman, Hort Sci. 41, 99-107 (2006)

5. T. R. Abu-Zahra, K. Al-Ismail, F. Shatat, Effect of organic and conventional systems on fruit quality of strawberry (Fragaria X Ananassa Duch) grown under plastic house conditions in the Jordan valley, in Proceedings of the 1st International Symposium on Fresh Food Quality Standards, Better Food by Quality and Assurance, 7-11 May 2006, Amman, Jordan (2007)

6. C. V. T. do Amarante, C. A. Steffens, Á. L. Mafra, J. A. Albuquerque, Pesq. Agropec. Bras. 43, 333-340 (2008)

7. M. K. Rai, P. Asthana , V. S. Jaiswal, U. Jaiswal, Trees 24, 1-12 (2010)

8. S. Supapvanich, Y. Kernprie, P. Boonyaritthongchai, C. Techavuthiporn, R. Tepsorn, P. Youryon, Emir. J. Food. Agr. 31, 395-404 (2019)

9. Carbon-nitrogen-ratio-management.

URL: https://www.aquaculturealliance.org/advocate/carbon-nitrogen-ratiomanagement/\#: :text=The\%20C\%3AN\%20ratio\%20in,become\%20pond $\% 20$ soil $\% 20$ organic $\% 20$ matter.

10. P. Suchatkun, Para Rubber Electronic Bulletin 29, 15-24 (2017)

11. N. N. Mohsenin, Physical Properties of Plants and Animal Materials (Gordon and Breach Science Publishers, New York, U.S.A.,1986)

12. S. Q. Liew, N. L. Chin, Y. A. Yusof, Agric. Agric. Sci. Procedia 2, 231-236 (2014)

13. Operation manual: chemical soil analysis and examination process. URL: http://www.ldd.go.th/PMQA/2553/Manual/OSD-03.pdf

14. What Does Manure Do to Soil? URL: https://homeguides.sfgate.com/manure-soil70424.html

15. E. M. Yahia, Postharvest Biology and Technology of Tropical and Subtropical Fruits Volume 3: Cocona to Mango (Woodhead Publishing Limited, Oxford, UK, 2011) 